\title{
Article \\ A Novel Biocompatible Ternary Nanoparticle with High Antibacterial Activity: Synthesis, Characterization, and Its Application in Beef Preservation
}

\author{
Lin Lin ${ }^{1,2} \mathbb{D}$, Chencheng Luo ${ }^{1}$, Changzhu $\mathrm{Li}^{2}$, Xiaochen Chen ${ }^{1}$ and Haiying Cui ${ }^{1, * \mathbb{D}}$ \\ 1 School of Food and Biological Engineering, Jiangsu University, Zhenjiang 212013, China; \\ lin1@ujs.edu.cn (L.L.); kjld2008@126.com (C.L.); 1000005533@ujs.edu.cn (X.C.) \\ 2 State Key Laboratory of Utilization of Woody Oil Resource, Hunan Academy of Forestry, \\ Changsha 410007, China; lichangzhu2013@aliyun.com \\ * Correspondence: cuihaiying@ujs.edu.cn
}

Citation: Lin, L.; Luo, C.; Li, C.; Chen, X.; Cui, H. A Novel Biocompatible Ternary Nanoparticle with High Antibacterial Activity: Synthesis, Characterization, and Its Application in Beef Preservation. Foods 2022, 11, 438. https://doi.org/10.3390/ foods11030438

Academic Editor: Pascal Degraeve

Received: 5 January 2022

Accepted: 29 January 2022

Published: 2 February 2022

Publisher's Note: MDPI stays neutral with regard to jurisdictional claims in published maps and institutional affiliations.

Copyright: (C) 2022 by the authors. Licensee MDPI, Basel, Switzerland. This article is an open access article distributed under the terms and conditions of the Creative Commons Attribution (CC BY) license (https:// creativecommons.org/licenses/by/ $4.0 /)$.

\begin{abstract}
Edible nanoparticles containing antibacterial agents are one of the effective strategies to control foodborne diseases. Herein, novel ternary nanoparticles (TNP) were prepared from rosemary essential oil (REO), nisin and Lycium barbarum polysaccharides (LBP) through hydrophobic and electrostatic interaction. The average particle size of TNP was $211.5 \mathrm{~nm}$, and its encapsulation efficiency reached $86.6 \%$. After the addition of LBP, the physical stability, thermal stability and storage stability of TNP were significantly improved. In vitro, compared with the control group, the population of S. aureus and E. coli O157:H7 in the TNP-treated group was reduced by $2.386 \log$ $\mathrm{CFU} / \mathrm{mL}$ and $1.966 \log \mathrm{CFU} / \mathrm{mL}$, respectively, on the fifth day. The free radical scavenging rate of TNP was $63.15 \%$. The application of TNP on beef presented favorable preservation effects without affecting its color and texture. Therefore, the synthesis strategy of TNP has important reference significance for the research and development of new food antibacterial agents.
\end{abstract}

Keywords: ternary nanoparticle; encapsulation efficiency; stability; antimicrobial activity; antioxidant activity

\section{Introduction}

Foodborne diseases caused by foodborne pathogenic microorganism contamination have high morbidity and mortality worldwide [1,2]. According to WHO statistics, about 600 million cases of foodborne diseases occur every year, and more than 420,000 people lose their lives as a result [3]. Foodborne pathogenic microorganisms mainly include orally transmitted bacteria, viruses, and parasites. Among them, foodborne pathogens, such as Staphylococcus aureus, Salmonella, Listeria monocytogenes and Escherichia coli played the most critical role in food safety problems [4]. In recent years, in order to overcome the shortcomings of traditional food antibacterial strategies, the development of new packaging and coating materials containing natural antibacterial agents based on nanotechnology has become one of the new strategies to reduce foodborne diseases [5]. Nanocarrier technologies including nanoparticles, nanoemulsions, nanohydrogels, nanoliposomes and nanofibers have been widely used in the field of food safety [6]. Nikolic et al. synthesized metal oxide nanoparticles as intelligent food packaging and found that metal oxide packaging exhibited better antibacterial potential [7]. Chitosan nanoemulsion can be used to preserve the quality of muscle foods [8]. Fucinos et al. studied smart nanohydrogels for controlled release of food preservatives [9]. Our research group has extensively studied the effect of nanoliposomes and nanofibers on prolonging the action time of essential oils and the preservation effect of nanoliposomes and nanofibers in food application [10-13].

As a new type of food additive, functional nanoparticles with food-grade biological macromolecules such as protein and polysaccharides as the main components have been extensively studied because of their large specific surface area, good biocompatibility, simple 
preparation process, and flexible structure [14,15]. In order to further improve the stability of single-component nanoparticles based on protein or polysaccharides and increase their encapsulation efficiency of active ingredients, the development of multi-component functional nanoparticles has attracted more and more attention [16]. Li et al. synthesized lutein/zein/soybean polysaccharide nanoparticles and found that the encapsulation efficiency was more than $80 \%$. Meanwhile, the nanoparticles showed excellent $\mathrm{pH}$ stability and salt ion tolerance [17]. Wang et al. prepared curcumin/sodium caseinate/soybean polysaccharide nanoparticles and found that sodium caseinate had a stronger binding effect with curcumin, while soybean polysaccharide improved the environmental stability of nanoparticles [18]. Although these functional nanoparticles composed of a biologically active ingredient and two carrier molecules significantly improved the stability of nanoparticles, their activity duration is relatively short, and there is room for further improvement of antibacterial activity.

Herein, a novel ternary nanoparticle (TNP) containing two active ingredients and a carrier material were prepared from rosemary essential oil (REO), nisin and Lycium barbarum polysaccharides (LBP). Studies on this type of nanoparticle are still relatively few. As the main active ingredient, REO has good antibacterial and antioxidant effect [19-21], and can be considered as a suitable green alternative synthetic antibacterial agent to inhibit pathogens in food. Nisin is adopted not only as another active ingredient to achieve antibacterial and antioxidant effect [22-24], but also a peptide-based material of nanoparticles, encapsulating REO through hydrophobic interaction [25]. However, nisin easily interacts with food ingredients and is easily degraded by enzymes [26-28], which can be solved by combining nisin with biopolymers or by synthesizing nisin-loaded nanoparticles [29-32]. As a natural Chinese herbal medicine polysaccharide, LBP has a variety of biological activities, good biocompatibility, good selectivity, and low cytotoxicity [33-35]. In addition, Liu et al. (2021) found that LBP has a highly branched chain structure and is rich in hydroxyl groups, which can be used as a potential stabilizer for nanoparticles [36]. Therefore, LBP has the potential to be a stabilizer for REO/nisin nanoparticles (RNNP), which were combined with nisin by electrostatic interaction. In summary, in view of the instability of protein nanoparticles, we use a polysaccharide to modify the protein to improve the stability of the nanoparticles. On this basis, we prepared TNP with high encapsulation efficiency and high stability. Compared with most nanoparticles, the TNP prepared in this paper has dual active components in order to improve its antibacterial and antioxidant effect. We also demonstrated the improvement of the stability of TNP and its practical value through thermal stability, storage stability and application in beef.

\section{Materials and Methods}

\subsection{Materials and Bacterial Culture}

Staphylococcus aureus (S. aureus) ATCC 25,923 and Escherichia coli EHEC O157:H7 (E. coli O157:H7) CICC 21,530 were provided by the Beina Institute of Biotechnology (Beijing, China). The nutrient agar (NA) and nutrient broth (NB) were chosen as mediums and were cultivated at $37^{\circ} \mathrm{C}$ for 1 day. Rosemary essential oil (REO) was bought from JE International (Natural CBD, Shanghai, China). Nisin was provided by Zhejiang Silver Elephant Bioengineering Co., Ltd. (Taizhou, China). Lycium barbarum polysaccharides (LBP) were purchased from Jiangzhang Industrial Park (Baoji, China). Beef was purchased from Kaiyuan Supermarket (Zhenjiang, China).

\subsection{Synthesis of $T N P$}

LBP ( $3 \mathrm{mg} / \mathrm{mL}$ ) was dissolved in distilled water and stirred for $120 \mathrm{~min}$. Next, nisin ( $3 \mathrm{mg} / \mathrm{mL}, \mathrm{pH}=4$ ) was slowly dropped into the LBP solution and stirred for $1 \mathrm{~h}$. The mixed solution was centrifuged $(3500 \times g, 10 \mathrm{~min})$. The REO (2 Minimum Inhibitory Concentration, 2MIC) was dropped into the solution and stirred for $30 \mathrm{~min}$. Finally, it was ultrasonicated for $10 \mathrm{~min}(600 \mathrm{~W}$, duration $1 \mathrm{~s}$, intervals $1 \mathrm{~s})$. Different nanoparticles were prepared by the above method: nanoparticles-I (LBP:nisin = 0:1, v:v), nanoparticles-II 
(LBP:nisin = 1:3, v:v), nanoparticle-III (LBP:nisin = 1:1, v:v), nanoparticles-VI (LBP:nisin = $3: 1, \mathrm{v}: \mathrm{v})$, nanoparticles-V (LBP:nisin = 5:1, v:v).

\subsection{Characterization of TNP}

\subsubsection{Particle Size, PDI and Encapsulation Efficiency of Nanoparticles}

The particle size and polymer dispersity index (PDI) of different nanoparticles were measured by a laser particle size analyzer (Nano ZS90, Malvern Instruments, Worcester, UK). The standard curve of REO was obtained through GC-MS (6890 GC/5973 NMSD, Agilent, Palo Alto, CA, American) [37]. The initial temperature was $60^{\circ} \mathrm{C}$ for $1 \mathrm{~min}$, then the temperature was raised to $120^{\circ} \mathrm{C}$ at $4{ }^{\circ} \mathrm{C} / \mathrm{min}$ and raised to $150{ }^{\circ} \mathrm{C}$ at $10^{\circ} \mathrm{C} / \mathrm{min}$ for 5 min. Finally, the temperature was raised to $250{ }^{\circ} \mathrm{C}$ at the same rate and kept for $3 \mathrm{~min}$. The essential oil concentrations were $1,2,4,6$ and $8 \mu \mathrm{L} / \mathrm{mL}$, and the injection volume was $1 \mu \mathrm{L}$. The concentration of REO embedded in different nanoparticles was determined by GC-MS. The following Formula (1) obtained the encapsulation efficiency (EE\%) of the nanoparticles.

$$
\mathrm{EE} \%=\mathrm{A} / \mathrm{T} \times 100 \%
$$

where $\mathrm{A}$ is the amount of essential oil contained and $\mathrm{T}$ is the total essential oil content [38].

\subsubsection{The Morphology of Nanoparticles}

Scanning electron microscopy (SEM) (COXEM EM-30 Plus, Daejeon, Korea) and an atomic force microscope (AFM) (Multimode 8 of Bruker, Mass) were used to observe the morphology of nanoparticles. The lyophilized nanoparticles (nanoparticles-I (LBP:nisin = 0:1, v:v) and nanoparticle-III (LBP:nisin = 1:1, v:v)) were rehydrated. They were then evenly dropped on the silicon wafer and dried with liquid nitrogen. SEM observed the morphology of the gold sprayed samples. The sample pre-treatment of AFM was the same as that of SEM. The rehydrated nanoparticles were dropped onto a mica sheet and observed with AFM.

\subsubsection{UV-Vis Absorption Spectrum}

UV-vis absorption spectrum was used to analyze the hydrophobicity of substances. The UV spectra was scanned by spectrophotometer (UV-1801, Rayleigh, Beijing, China). The scanning range was 190-900 nm, and the scanning interval was $1 \mathrm{~nm}$.

\subsubsection{Fluorescence Spectroscopy Measurement}

A fluorescence spectrophotometer (F-4500, Hitachi, Japan) was used to scan the fluorescence spectrum. The excitation wavelength was $280 \mathrm{~nm}$, the wavelength range was $300-500 \mathrm{~nm}$, the scanning speed was $1000 \mathrm{~nm} / \mathrm{min}$, and the excitation bandwidth was $10 \mathrm{~nm}$.

\subsubsection{Fourier Transform Infrared Spectroscopy (FTIR) Analysis of Nanoparticles}

In order to analyze the interaction between nisin and LBP, and whether REO was encapsulated by nanoparticles, we carried out a Fourier transform infrared spectroscopy (FTIR). The scanning range of the infrared spectrum was $800-4000 \mathrm{~cm}^{-1}$, and the scanning times were 32 [39].

\subsubsection{Quartz Crystal Microbalance (QCM)}

To verify the encapsulation effect of nisin nanoparticles (NNP) on REO and the modification effect of LBP on RNNP, the minor mass differences among NNP, RNNP, and TNP were analyzed by quartz crystal microbalance (QCM) (Q-Sense E4, Baiolin, Swedish). The solvent was deionized water with a flow rate of $100 \mu \mathrm{L} / \mathrm{mL}$. The small mass differences between the three nanoparticles were measured in terms of frequency $(\Delta \mathrm{F})$ and energy $\operatorname{loss}(\Delta \mathrm{D})[40]$. 


\subsubsection{X-ray Diffraction (XRD)}

The X-ray diffraction (XRD) was carried out at $40 \mathrm{kV}$ and $40 \mathrm{~mA}$ by X-ray diffractometer (D8 ADVANCE, Brook, Germany) to analyze the crystallinity of nanoparticles. The scanning range of the diffraction pattern was $4-90^{\circ}(2 \theta)$, and the scanning rate was $5.0^{\circ} / \mathrm{min}[41]$.

\subsection{Stability of Nanoparticles}

The thermogravimetric analysis (TGA) and differential scanning calorimetry (DSC) were analyzed by a thermal analyzer (STA449F3, NETZSCH, Selb, Germany). The sample $(5 \mathrm{mg})$ was weighed and heated from room temperature to $800^{\circ} \mathrm{C}$. The temperature rose at $10{ }^{\circ} \mathrm{C} / \mathrm{min}$, and the weight loss of each sample was recorded [42].

The particle size and PDI of nanoparticles were determined under different $\mathrm{pH}(2-7)$ and ionic strength ( $\mathrm{NaCl}$ concentration: $0-100 \mathrm{mmol} / \mathrm{L}$ ) to observe the physical stability of nanoparticles. TNP were stored at $4{ }^{\circ} \mathrm{C}$. The particle size and PDI were measured at 0,5 , $10,15,20,25$ and 30 days to analyze the storage stability of nanoparticles.

\subsection{Antibacterial Effect of Nanoparticles}

The antibacterial effect of nanoparticles was evaluated by the inhibition zone, transmission electron microscope (TEM), and time-kill curve. First, we took $100 \mu \mathrm{L}$ bacterial solution (bacteria concentration $10^{6}-10^{7}$ ) and coated the plate, then a filter paper with a diameter of $10 \mathrm{~mm}$ was stuck in the middle of the plate. Nanoparticles $(10 \mu \mathrm{L})$ were dropped on the filter paper, and put it into the incubator. The size of the inhibition zone was measured.

The structure of bacteria was measured by TEM. The bacteria (bacteria concentration $10^{4}-10^{5}$ ) were treated with different nanoparticles (RNNP and TNP) for $4 \mathrm{~h}$, the concentration of nanoparticles was $40 \%$, and the bacteria not treated with nanoparticles were used as control. Next, each sample was centrifuged at $8000 \mathrm{rpm}$ for $5 \mathrm{~min}$. Then the copper mesh was immersed in the washed bacterial suspension, left for $3 \mathrm{~min}$, and dried. The copper mesh with the bacteria was then stained in a $3 \%(\mathrm{w} / \mathrm{w})$ phosphotungstic acid solution for $15 \mathrm{~min}$ and dried. Finally, the product was observed by TEM (JSM-7001F, Japan).

The bacteria (bacteria concentration $10^{4}-10^{5}$ ) were treated with different nanoparticles (RNNP and TNP), the concentration of nanoparticles was $40 \%$, and the bacteria not treated with nanoparticles were used as control. The plate colony counting method was used to record the daily changes in the number of bacteria to reflect the bactericidal effect of the nanoparticles within five days.

\subsection{Antioxidant Effect of Nanoparticles}

\subsubsection{DPPH Scavenging Activity}

Different samples $(1 \mathrm{~mL})$ were mixed with $3 \mathrm{~mL}$ DPPH $(0.1 \mathrm{mmol} / \mathrm{L})$ and then were placed in the dark for $30 \mathrm{~min}$ and the absorbance at $517 \mathrm{~nm}$ were measured by spectrophotometer. The antioxidant activity can be obtained by the following Formula (2).

$$
\text { Antioxidant activity }=\left[1-\left(\mathrm{A}_{2}-\mathrm{A}_{1}\right) / \mathrm{A}_{0}\right] \times 100 \%
$$

$\mathrm{A}_{0}$ was the absorbance of blank, $\mathrm{A}_{2}$ was the absorbance of the sample reacted with $\mathrm{DPPH}$, and $\mathrm{A}_{1}$ was the absorbance of the sample reacted with ethanol [43].

\subsubsection{Antioxidant Effect on Beef}

Mix beef $(3 \mathrm{~g})$ from different treatment groups with trichloroacetic acid solution (TCA, $15 \mathrm{~mL}$ ) were beaten with a sterile homogenizer for $2 \mathrm{~min}$, and filtered. The filtrate was mixed with thiobarbituric acid solution (TBA, $5 \mathrm{~mL}$ ) and then heated in a water bath $\left(100^{\circ} \mathrm{C}\right)$ for $30 \mathrm{~min}$. The mixture was centrifuged after cooling to room temperature. The 
absorbance of the supernatant was measured at $532 \mathrm{~nm}$. The TBA of the sample was calculated according to the following Formula (3) [44].

$$
\mathrm{TBA}(\mathrm{mg} / \mathrm{kg})=\mathrm{A} / \mathrm{m} \times 9.48
$$

Different beef homogenate samples were mixed with $30 \mathrm{~mL}$ of sterile water, and were incubated with shaking at $37^{\circ} \mathrm{C}$ for $30 \mathrm{~min}$. After filtering and centrifuging the mixture, 10 $\mathrm{mL}$ of the supernatant was taken and mixed with an equal volume of $\mathrm{MgO}$ solution $(1 \%$, $\mathrm{w}: \mathrm{v})$. After distilling for $5 \mathrm{~min}$, the boric acid solution $(2 \%, \mathrm{w}: \mathrm{v})$ containing $5-6$ drops of methyl red-methylene blue mixed indicator was used to absorb the volatile nitrogenous substances in the distillate. A hydrochloric acid solution $(0.01 \mathrm{~mol} / \mathrm{L})$ was used to titrate the above-mentioned boric acid solution containing volatile nitrogen substances. The volume of hydrochloric acid solution consumed was recorded. An equal volume of deionized water replaced the sample supernatant as a blank test, and the following Formula (4) was used to calculate the TVB-N value in different samples:

$$
\operatorname{TVB}-\mathrm{N}(\mathrm{mg} / 100 \mathrm{~g})=\left\{\left[\left(\mathrm{V}_{1}-\mathrm{V}_{2}\right) \times \mathrm{C} \times 14\right] /(\mathrm{m} \times 5 / 100)\right\} \times 100
$$

$\mathrm{V}_{1}$ and $\mathrm{V}_{2}$ were the volume of the hydrochloric acid solution consumed by the sample and blank (mL), individually, $\mathrm{C}$ was the concentration of the hydrochloric acid solution $(\mathrm{mol} / \mathrm{L}), \mathrm{m}$ was the mass of the sample $(\mathrm{g})$, and the conversion factor was 14 [44].

\subsection{The Application of Nanoparticles against S. aureus and E. coli O157:H7 on Beef}

The beef was cut into equal sized pieces (mass about $3 \mathrm{~g}$ ). It was soaked in nanoparticles for $10 \mathrm{~min}$ at room temperature, then an appropriate number of bacteria $\left(10^{4}-10^{5}\right)$ were added to the beef. The treated beef was placed at 4 and $25^{\circ} \mathrm{C}$ for 5 days. The plate colony counting method was used to record the daily changes in colonies.

\subsection{Characterization of Coated Beef}

The color, $\mathrm{pH}$ and texture of beef in different treatment groups were also recorded. The color was performed by a Colorimeter ( $3 \mathrm{nh}$, Shenzhen sanenshi Technology Co., Ltd., Shenzhen, China). The $\mathrm{pH}$ was measured using a $\mathrm{pH}$ meter according to Chinese standard GB 5009.237-2016. Surface texture measurement of the beef was performed using a texture analyzer (ST-Z16, Shandong Shengtai Instrument Co., Ltd., China). The specific parameters were as follows: the test speed was $5.00 \mathrm{~mm} / \mathrm{s}$, the strain was $50 \%$, and the trigger force was $5.0 \mathrm{~g}$.

\subsection{Statistical Analysis}

Three parallel groups were set in each group. The results were analyzed by SPSS (version 26.0; IBM Corp., Armonk, NY, USA), which was expressed as mean \pm standard deviation (SD).

\section{Results and Discussion}

\subsection{Characterization of Nanoparticles}

\subsubsection{Particle Size, PDI and Encapsulation Efficiency of Nanoparticles}

The results of particle size, PDI and morphology of nanoparticles showed that TNP were successfully prepared. Table 1 showed the particle size, PDI, and encapsulation efficiency of nanoparticles with different ratios, which are metrics for measuring nanoparticles [45]. When the particle size of nanoparticles is too tiny, nanoparticles are easy to agglomerate. When the particle size of nanoparticles is too large, the drug loading effect of the nanoparticle is not good. Nanoparticle I was RNNP with a particle size of $167.8 \pm 4.8 \mathrm{~nm}$, PDI of $0.242 \pm 0.008$, and encapsulation efficiency of $53.7 \% \pm 0.6$. Nanoparticles II to $\mathrm{V}$ were TNP, and the particle size became larger after the modification of binary nanoparticles by polysaccharides, ranging from $211.5 \pm 8.1 \mathrm{~nm}$ to $386.5 \pm 2.3 \mathrm{~nm}$, indicating that polysaccharides successfully modified the RNNP. When nisin was more abundant, the 
particle size was $386.5 \pm 2.3 \mathrm{~nm}$, PDI was $0.302 \pm 0.022$, and the encapsulation efficiency was lowest at $84.4 \% \pm 0.3$. These results showed that the formed TNP were uneven in distribution and large in size. This distribution was due to the fact that there were not enough LBP to modify nisin. The clumping of nisin occurred, and the hydrophobic effect between nisin and REO was weak. When the ratio of nisin to LBP was 1:1, the particle size was the smallest, the encapsulation efficiency was the highest, and the PDI was less than 0.3 , so nisin: $\mathrm{LBP}=1: 1$ was the optimal ratio. At this time, LBP fully modified nisin to expose more hydrophobic bonds, which enhanced the hydrophobic effect between nisin and REO. When LBP was in excess of nisin, the particle size began to increase. This increase was due to the accumulation of excess LBP on the surface of nisin. PDI indicated the degree of dispersion of nanoparticles; except for nanoparticle II, the PDI of the rest of the nanoparticles were all less than 0.3 , indicating that the nanoparticles had good dispersion. Encapsulation efficiency is one of the most critical indicators of nanoparticles. Compared with RNNP, the different ratios of the prepared TNP all showed improved encapsulation efficiency, ranging from $84.4 \% \pm 0.3$ to $86.6 \% \pm 0.2$. These results indicated that nisin nanoparticles modified by LBP could improve their encapsulation efficiency.

Table 1. The Particle size, PDI and encapsulation efficiency of nanoparticles.

\begin{tabular}{ccccc}
\hline Nanoparticles & Nisin:LBP (V/V) & Particle Size (nm) & PDI & $\begin{array}{c}\text { Encapsulation } \\
\text { Efficiency (\%) }\end{array}$ \\
\hline Nanoparticles-I & $1: 0$ & $167.8 \pm 4.8$ & $0.242 \pm 0.008$ & $53.7 \pm 0.6$ \\
Nanoparticles-II & $3: 1$ & $386.5 \pm 2.3^{\mathrm{a}}$ & $0.302 \pm 0.022^{\mathrm{a}}$ & $84.4 \pm 0.3^{\mathrm{c}}$ \\
Nanoparticles-III & $1: 1$ & $211.5 \pm 8.1^{\mathrm{d}}$ & $0.241 \pm 0.002^{\mathrm{c}}$ & $86.6 \pm 0.2^{\mathrm{a}}$ \\
Nanoparticles-VI & $1: 3$ & $266.7 \pm 7.7^{\mathrm{b}}$ & $0.269 \pm 0.005^{\mathrm{b}}$ & $86.4 \pm 0.1^{\mathrm{a}}$ \\
Nanoparticles-V & $1: 5$ & $256.3 \pm 8.4^{\mathrm{c}}$ & $0.227 \pm 0.015^{\mathrm{c}}$ & $85.6 \pm 0.3^{\mathrm{b}}$ \\
\hline
\end{tabular}

Values are expressed as mean \pm SD. ${ }^{a-d}$ Different superscript within the same column represent significant differences $(p<0.05)$.

\subsubsection{Morphology Analysis of Nanoparticles}

The SEM-micrographs and AFM images of RNNP and RNNP modified by polysaccharides were presented in Figure 1. The two kinds of nanoparticles were uniformly spherical. After the modification of nanoparticles with polysaccharides, the particle size of RNNP became larger.
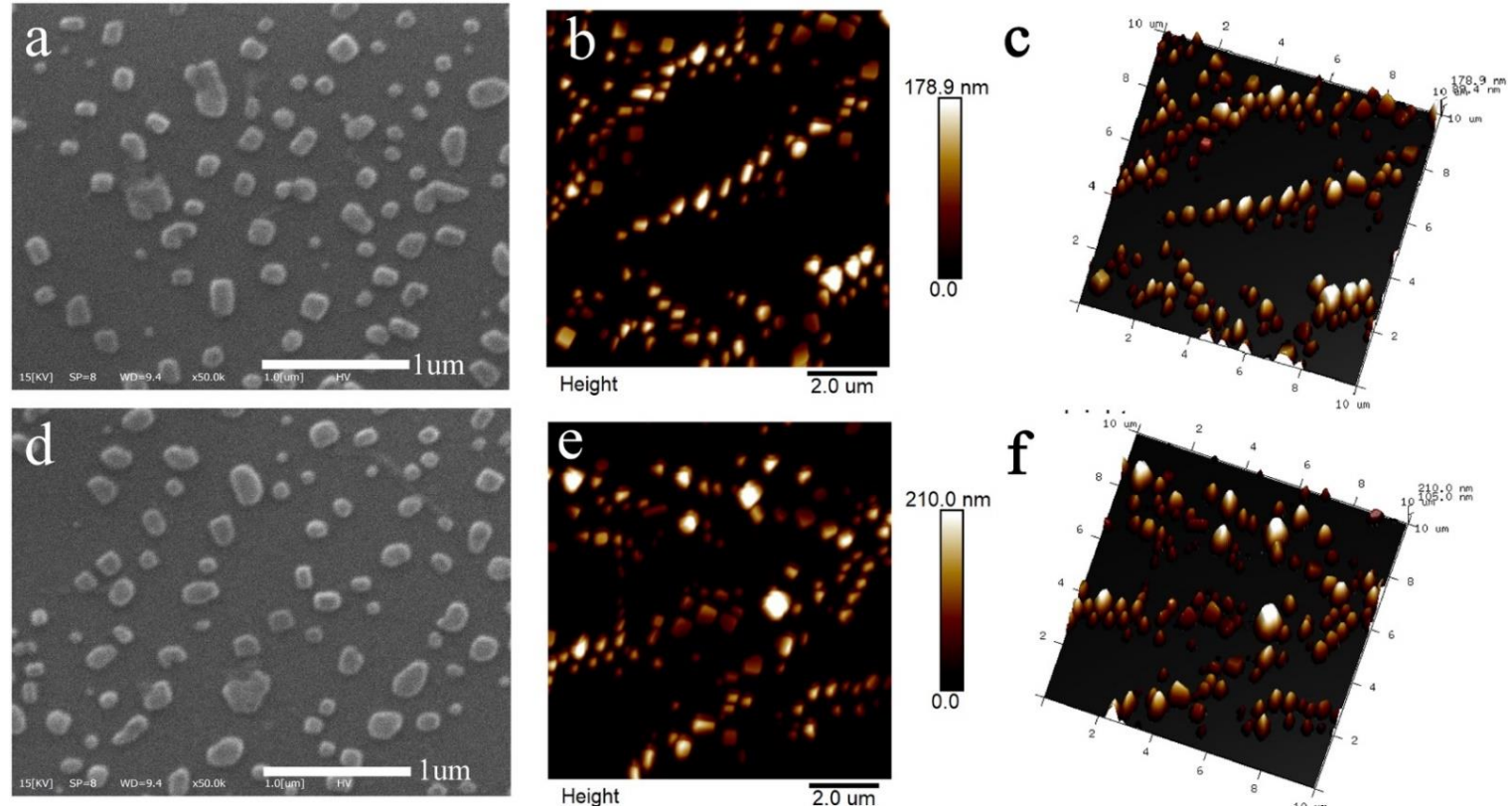

Figure 1. The morphology of nanoparticles including SEM-micrographs and surface, 3-Dimensional AFM images of RNNP (a-c) and TNP (d-f). 


\subsubsection{UV-Vis Spectral Analysis}

The increase of the encapsulation efficiency of TNP may be due to the more hydrophobic bonds exposed by the interaction between protein and polysaccharide. The results of UV and fluorescence spectra were consistent with our conjecture. The increase of encapsulation efficiency was due to more water dispersing bonds exposed by the interaction of protein and polysaccharide. In addition, we found other results. As shown in Figure 2a, the maximum absorption peak of nisin appeared at $223 \mathrm{~nm}$, consistent with previous studies [46]. The absorption peaks of NNP and nisin/LBP nanoparticles (NLNP) were red-shifted to $226 \mathrm{~nm}$ and $231 \mathrm{~nm}$, respectively, which may be due to the enhanced hydrophobicity of nanoparticles [47]. In addition, the NLNP red-shifted to a greater extent than NNP, which indicated that NLNP exposed more hydrophobic bonds. These results further proved that nisin modified by polysaccharides could improve the encapsulation efficiency of nanoparticles.
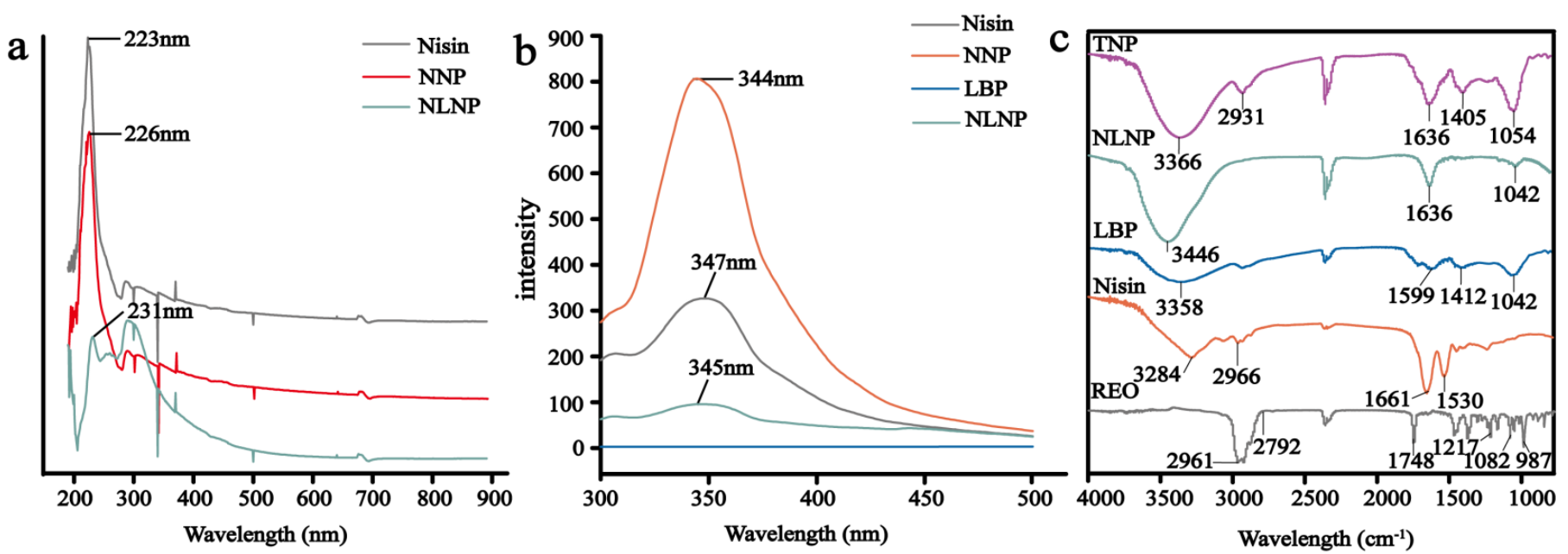

Figure 2. The spectral analysis of nanoparticles including UV-vis absorption spectrum(a) and Fluorescence spectroscopy(b) of Nisin, NNP and NLNP; FTIR spectrum(c) of REO, Nisin, LBP, NLNP and TNP.

\subsubsection{Fluorescence Spectroscopy Analysis}

As was shown in Figure 2b, the fluorescence peak of nisin appeared at $347 \mathrm{~nm}$, which was due to the existence of tryptophan residues. The result was consistent with Narahari et al. [48]. The fluorescence intensity of LBP was 0 , indicating that LBP had no fluorescence. Compared to free nisin, the fluorescence intensity of NNP was enhanced from 326.5 to 806.5 , which might be related to the enhanced conjugation degree when nanoparticles were formed. The fluorescent intensity of NLNP was weakened, which was attributed to the polysaccharides being barely band fluorescent. These results illustrated that nisin was encapsulated in the polysaccharides. The wavelengths corresponding to the fluorescence maxima of NNP and NLNP were blue-shifted from $347 \mathrm{~nm}$ to $344 \mathrm{~nm}$ and $345 \mathrm{~nm}$, respectively. This can be the result of the exposure of tryptophan residues to a more hydrophobic environment [49]. In addition, more hydrophobic bonds were exposed when nisin formed nanoparticles or nisin and LBP were combined to form complexes. This result was consistent with Li et al. [50]. The fluorescence spectra results illustrated that the binding of LBP to nisin had a certain effect on the microenvironment of tryptophan and even nisin. Furthermore, when nisin was made into nanoparticles or modified with polysaccharides, the hydrophobicity of NNP and NLNP could be increased to improve the encapsulation efficiency of essential oil. The fluorescence results were consistent with the results of the UV spectrum. In addition, the microenvironment with the enhanced hydrophobicity of protein can improve the stability of protein [51]. Therefore, nisin modified by LBP not only improved the encapsulation efficiency of nanoparticles, but also improved its stability. 


\subsubsection{Infrared Spectroscopic Analysis of Nanoparticles}

The main reasons for the formation of TNP are hydrophobic interaction and electrostatic interaction. The results of FTIR presented the interaction between the materials during the formation of nanoparticles. Figure 2c presented the FTIR spectrum of REO, nisin, LBP, NLNP and TNP. As shown in the FTIR spectrum of REO, from $2795 \mathrm{~cm}^{-1}$ to $2961 \mathrm{~cm}^{-1}$ there were C-H stretching bands. $1748 \mathrm{~cm}^{-1}$ was the peak of the keto of camphor. The peak at $987 \mathrm{~cm}^{-1}$ and $1217 \mathrm{~cm}^{-1}$ was due to the ether function of an epoxy ring of 1, 8-cineole. The peak at $1082 \mathrm{~cm}^{-1}$ was related to the asymmetric stretching of the C-O bond $[52,53]$. The FTIR spectrum of nisin showed that the peak at $3284 \mathrm{~cm}^{-1}$ was due to the axial tensile vibration of O-H and N-H. The peak at $2966 \mathrm{~cm}^{-1}$ was attributed to the tensile vibration of $\mathrm{C}-\mathrm{H}$. The peak at $1661 \mathrm{~cm}^{-1}$ was the absorption peak of the amide band, and the peak at $1530 \mathrm{~cm}^{-1}$ was related to the bending of the primary amine [54]. The peaks of LBP appeared at $1045 \mathrm{~cm}^{-1}$ (C-O), $1599 \mathrm{~cm}^{-1}$ (COO- stretching) and $3358 \mathrm{~cm}^{-1}$ (O-H stretching vibration), which were also the common characteristic peaks of polysaccharides [55]. The $\mathrm{N}-\mathrm{H}$ stretching peak of nisin in NLNP was at $3449 \mathrm{~cm}^{-1}$, and the N-H stretching peak of nisin was at $3284 \mathrm{~cm}^{-1}$. This was due to the new intramolecular hydrogen bond between the N-H group of nisin and the O-H stretching of LBP [56]. In addition, the COOchanged from $1599 \mathrm{~cm}^{-1}$ to $1636 \mathrm{~cm}^{-1}$, and the primary amine peak of nisin changed from $1530 \mathrm{~cm}^{-1}$ to $1636 \mathrm{~cm}^{-1}$. It indicated that there was electrostatic interaction between nisin and LBP, which was one of the crucial reasons for the formation of nanoparticles [54]. Compared with the infrared spectra of NLNP, TNP had a characteristic peak at $2932 \mathrm{~cm}^{-1}$, which was the C-H stretching band of REO, and the absorption peak at $1054 \mathrm{~cm}^{-1}$ was enhanced. These results showed that NLNP successfully encapsulated REO.

\subsubsection{QCM}

The results of QCM further showed that REO was successfully embedded in nanoparticles [57]. As was shown in Figure 3a, the changes of frequency $(\Delta \mathrm{F})$ and energy loss $(\Delta \mathrm{D})$ showed that the three types of nanoparticles had good adsorption with the gold carrier. The energy loss of the three types of nanoparticles changed little, and the frequency changed significantly. Compared with NNP, the $\Delta \mathrm{F}$ and $\triangle \mathrm{D}$ of RNNP became larger. These results showed that REO was successfully embedded in NNP, resulting in the increase of its mass. Compared with RNNP, the mass of TNP increased. These results showed that LBP modified RNNP.
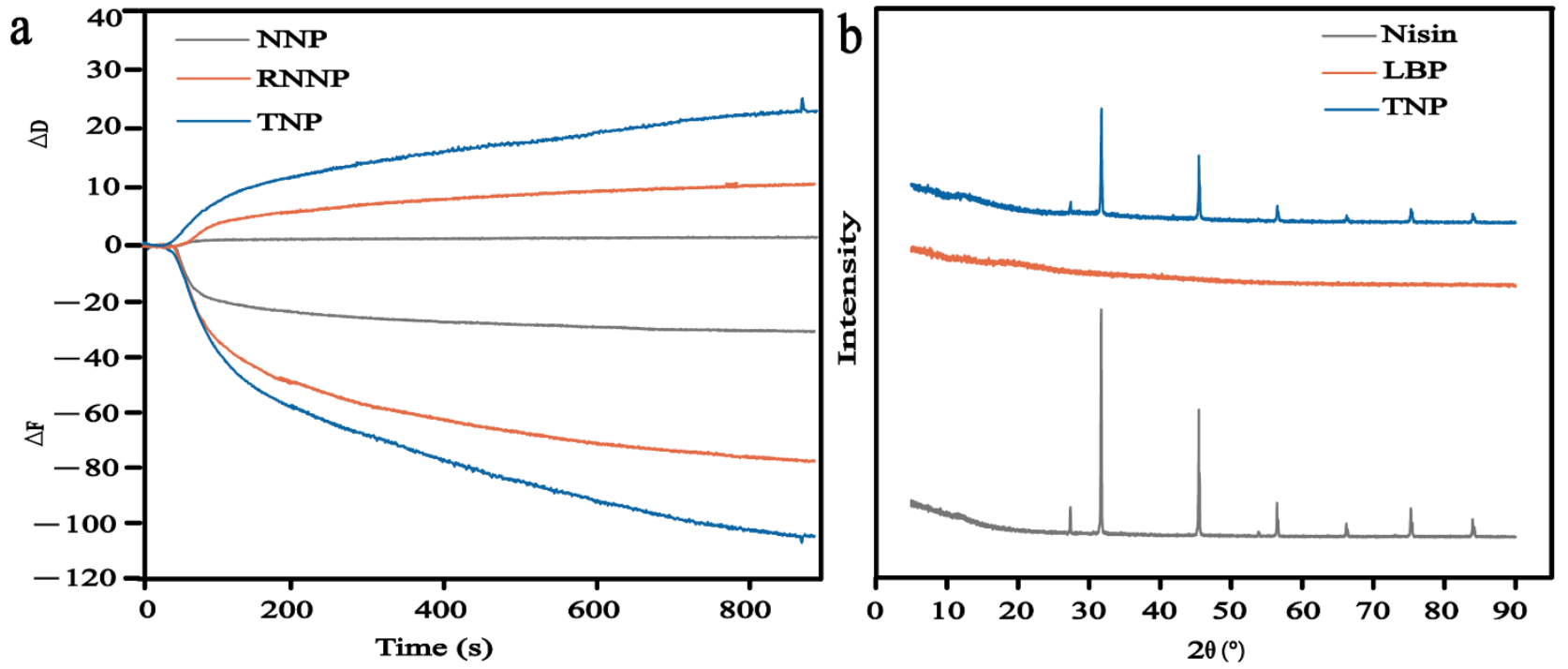

Figure 3. QCM of NNP, RNNP and TNP (a); XRD of Nisin, LBP and TNP(b). 


\subsubsection{XRD}

Figure $3 b$ was $X R D$ of nisin, LBP, and TNP, which can analyze the crystallinity of the substance. The diffraction peaks of nisin were found at $32^{\circ}, 46^{\circ}$ and $56^{\circ}$. These results showed that nisin was crystalline, which was consistent with the results of Chang et al. [47]. The XRD pattern of LBP was a straight line, which proved that LBP was an amorphous structure. The XRD pattern of TNP was the same as that of nisin, indicating that TNP did not damage the crystal structure of nisin. However, the intensity of three diffraction peaks $\left(32^{\circ}, 46^{\circ}\right.$ and $\left.56^{\circ}\right)$ of TNP all showed a decreasing trend. On the one hand, the original absorption peak of nisin was weakened due to the connection of nisin and REO after encapsulation. The inclusion of REO with nisin formed a new phase. On the other hand, nisin was encapsulated in LBP, and there was electrostatic interaction between them.

\subsection{The Stability of Nanoparticles}

The thermal stability of nanoparticles was evaluated by TGA and DSC. The results were presented in Figure 4. As can be seen from Figure 4a, nisin had strong thermal stability. When it was heated to $800{ }^{\circ} \mathrm{C}$, the weight loss was $16.96 \%$. The results were consistent with those of Zhang et al. [58]. At $296.3{ }^{\circ} \mathrm{C}$, the weight loss rate reached the maximum, and the weight loss was about $5.13 \%$. Figure $4 \mathrm{~b}$ was the TGA diagram of LBP, and its weight loss was $67.22 \%$. At $197.4^{\circ} \mathrm{C}$, the weight loss rate was the highest, and the weight loss was $16.63 \%$. Figure $4 c$,d were the thermogravimetry diagrams of RNNP and TNP, respectively. Compared with the pure materials, the weight loss was reduced by $10.15 \%$ and $43.98 \%$, respectively. These results proved that when nisin and LBP were prepared into nanoparticles, their thermal stability was improved. In addition, the prepared nanoparticles had high thermal stability. The weight loss of LBP was $50.26 \%$ more than that of nisin. The weight loss of TNP was $33.83 \%$ more than that of RNNP, which was due to the fact that LBP was the outermost layer of TNP, and the weight loss of the polysaccharide was more significant at $800^{\circ} \mathrm{C}$. However, this value was lower than the increase in the weight loss of pure substance. It proved that the thermal stability of the nanoparticles could be improved by modifying RNNP with LBP. Compared with the DSC of nisin, the endothermic and exothermic behaviors of RNNP disappeared in the range of 300-600 ${ }^{\circ} \mathrm{C}$. The DSC of TNP was similar to that of LBP, and there was no endothermic and exothermic peak of nisin. These results indicated that nisin was encapsulated in LBP.
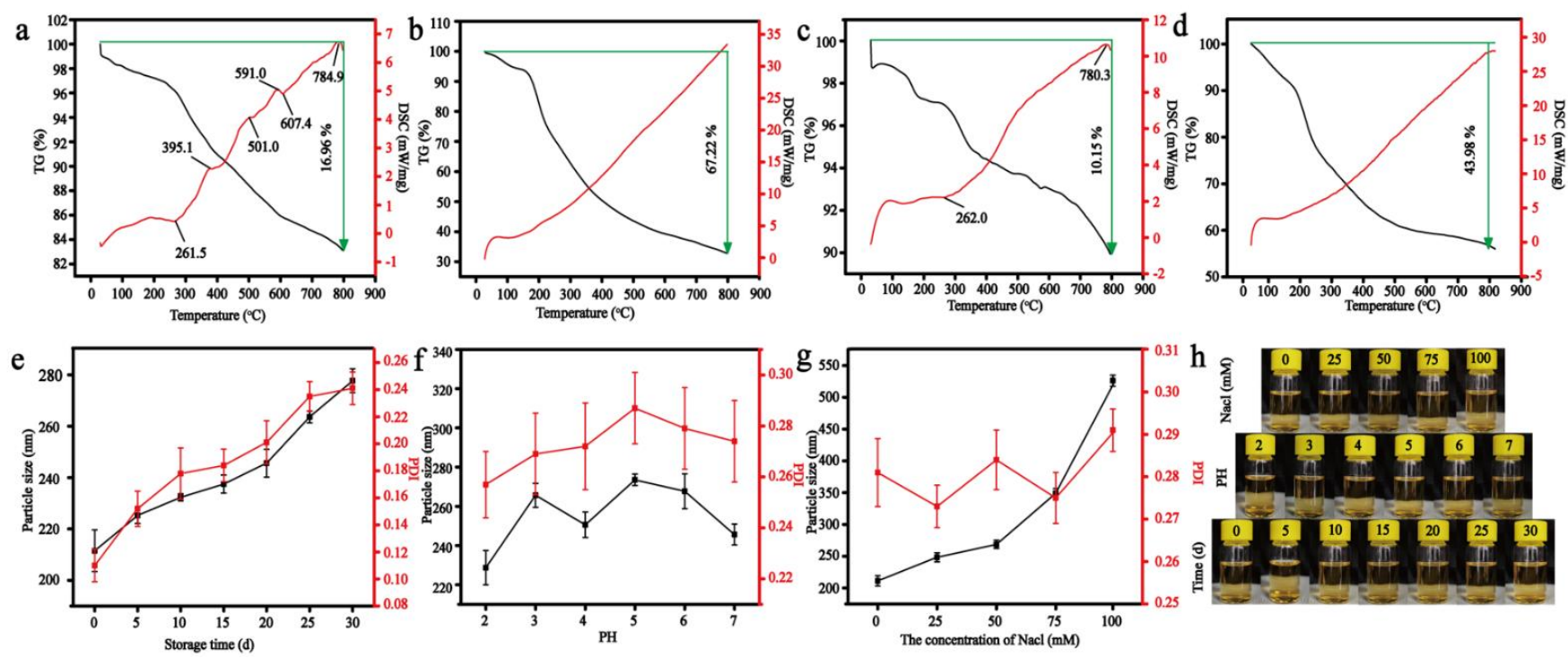

Figure 4. The stability of nanoparticles including the thermal stability of nanoparticles including TGA and DSC of Nisin (a), LBP (b), RNNP (c) and TNP (d) and the storage stability (e), physical stability (f,g) and picture (h) of TNP. 
Storage stability and physical stability were also used to evaluate the stability of TNP. The storage stability of TNP was shown in Figure 4a. With the increase of storage days, the particle size and PDI of TNP showed an increasing trend. On $0 \mathrm{~d}$, the particle size of TNP was $211.5 \pm 8.1 \mathrm{~nm}$, and the PDI was $0.110 \pm 0.012$. The particle size of TNP was $277.7 \pm 4.6 \mathrm{~nm}$, and the PDI was $0.241 \pm 0.012$ after being stored at $4{ }^{\circ} \mathrm{C}$ for 30 days. The particle size increased by $66 \mathrm{~nm}$. The change of particle size was small, and the PDI was less than 0.3 . These results indicated that the prepared TNP were more stable. Figure $4 \mathrm{~b}$ showed the particle size and PDI of TNP at different $\mathrm{pH}$. The maximum particle size was $273.5 \pm 2.9 \mathrm{~nm}$ when the $\mathrm{pH}$ was 5 . The minimum particle size was $228.7 \pm 8.7 \mathrm{~nm}$ when the $\mathrm{pH}$ was 2. The particle size of TNP at different $\mathrm{pH}$ was less than $300 \mathrm{~nm}$, and the PDI was less than 0.3 . These results proved that TNP were not sensitive to $\mathrm{pH}$. Figure $4 \mathrm{c}$ presented the stability of TNP in different salt ionic strengths. With the increase of salt ionic strength, the particle size of TNP also increased. When the concentration of sodium chloride was $75 \mathrm{mmol} / \mathrm{L}$, the particle size of TNP was $349.2 \pm 7.3 \mathrm{~nm}$. When the concentration of sodium chloride was $100 \mathrm{mmol} / \mathrm{L}$, the particle size of TNP was $526.1 \pm 8.7 \mathrm{~nm}$. These results showed that when the concentration of sodium chloride was less than $75 \mathrm{mmol} / \mathrm{L}$, TNP were more stable.

\subsection{Antimicrobial Effect of Nanoparticles}

The antibacterial effects of two kinds of nanoparticles on S. aureus and E. coli O157:H7 and the TEM were presented in Figure 5. Both types of nanoparticles showed good antimicrobial activity. The inhibition zones of RNNP on S. aureus and E. coli O157:H7 were $14 \mathrm{~mm}$ (Figure 5b) and $13 \mathrm{~mm}$ (Figure 5h), respectively. When the nanoparticles were modified with polysaccharides, the inhibition zones increased to $20 \mathrm{~mm}$ (Figure 5c) and $17 \mathrm{~mm}$ (Figure 5i). These results showed that the antibacterial activity of TNP was enhanced, and the result was consistent with the increase in the encapsulation rate.
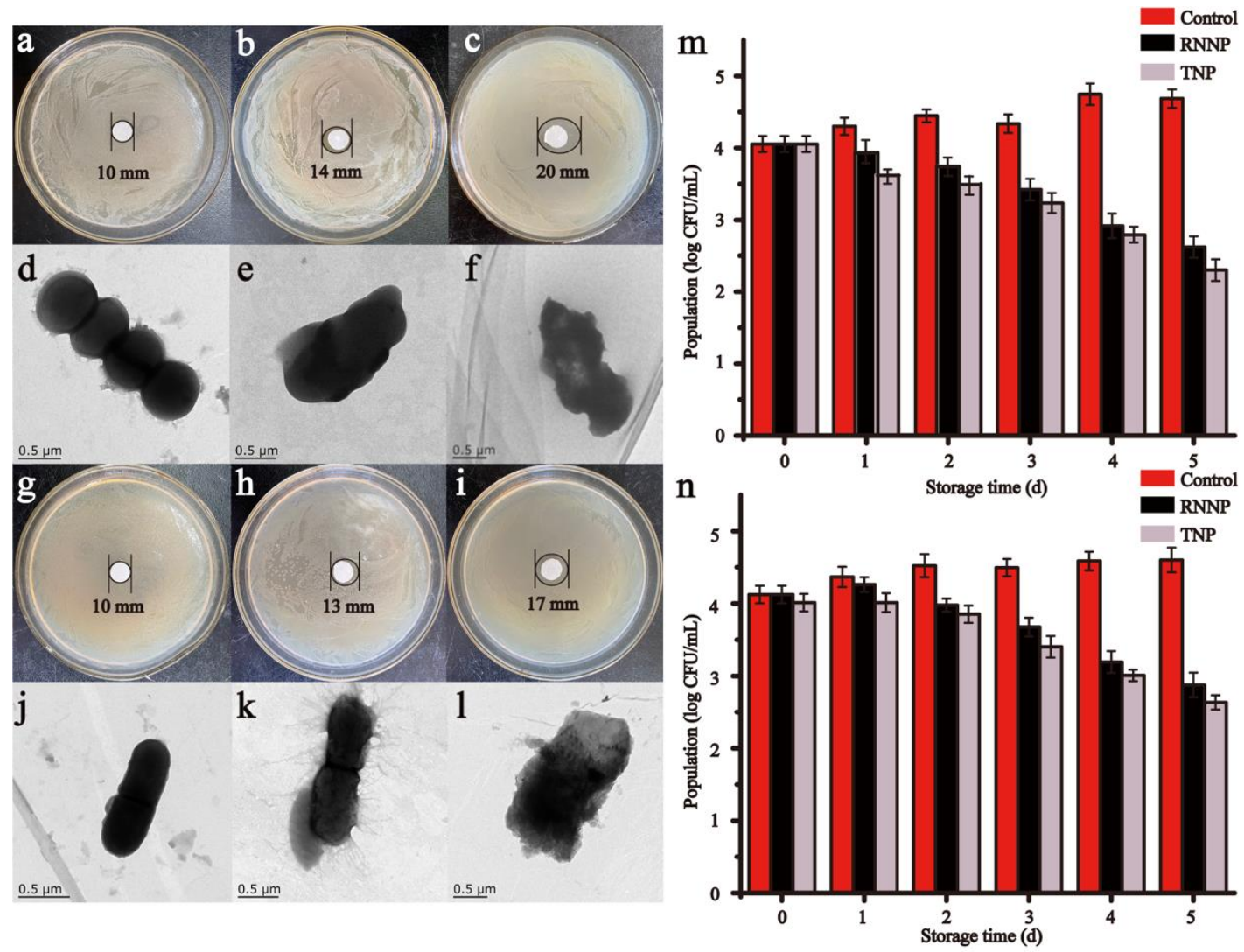

Figure 5. The antibacterial effect of nanoparticles including the inhibition zones, TEM and time-kill curve of control, RNNP and TNP on S. aureus (a-f,m) and E. coli O157:H7 (g-1,n). 
TEM images of bacteria showed similar results. Compared with RNNP, TNP caused more damage to bacteria. Figure 5d,j were TEM images of bacteria not treated with antimicrobial agents. The surface of the bacteria was smooth. Figure 5e,k were TEM images of bacteria treated with RNNP. The surface of the bacteria was slightly rough. Figure $5 f, 1$ were TEM images of bacteria treated with TNP, and the bacteria were destroyed entirely, and the contents were delivered.

The results of the time-kill curve further proved that the antibacterial effect of TNP was better than that of RNNP. The initial number of S. aureus and E. coli O157:H7 was $4.054 \log \mathrm{CFU} / \mathrm{mL}$ and $4.125 \log \mathrm{CFU} / \mathrm{mL}$, respectively. The number of $S$. aureus and E. coli O157:H7 were reduced by $2.064 \log \mathrm{CFU} / \mathrm{mL}$ and $1.727 \log \mathrm{CFU} / \mathrm{mL}$, respectively by RNNP, and TNP reduced the number of $S$. aureus and E. coli O157:H7 by $2.386 \log \mathrm{CFU} / \mathrm{mL}$ and $1.966 \log \mathrm{CFU} / \mathrm{mL}$, respectively within five days (Figure $5 \mathrm{~m}, \mathrm{n}$ ).

\subsection{Antioxidant Effect of Nanoparticles}

\subsubsection{DPPH Scavenging Ability}

The DPPH scavenging ability of nanoparticles and their antioxidant effects on beef were presented in Figure 6. The highest DPPH scavenging ability among the five samples was observed in TNP, which was 33.3\% higher than that of RNNP (Figure 6a). On the one hand, it was owed to the strong DPPH scavenging ability of LBP that reached $52.71 \%$. On the other hand, it was due to the higher encapsulation rate of TNP.
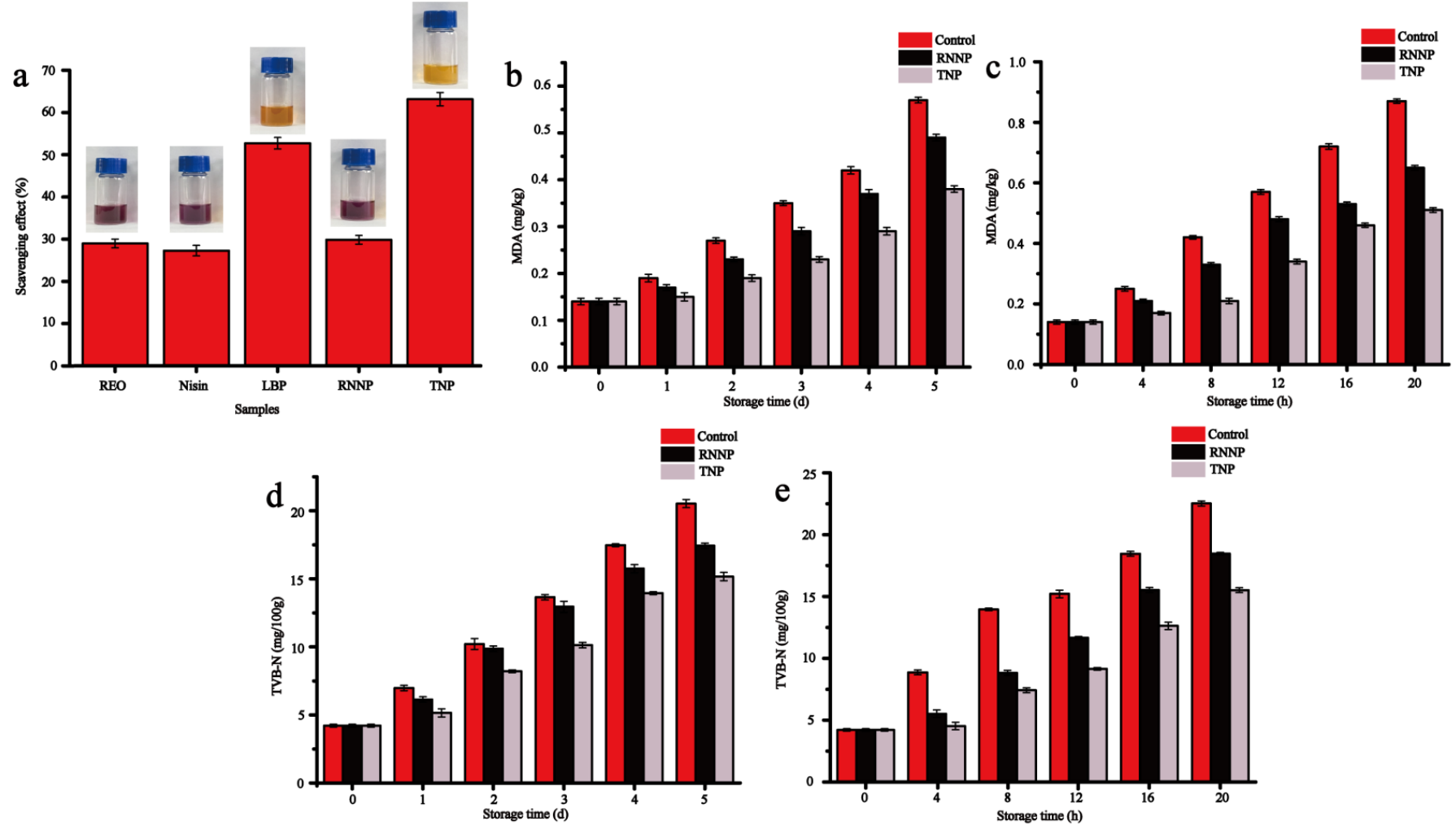

Figure 6. The antioxidation effect of nanoparticles including DPPH free radical scavenging capacity (a), TBA (b, c) and TVB-N (d, e) at $4{ }^{\circ} \mathrm{C}$ and $25^{\circ} \mathrm{C}$.

\subsubsection{Antioxidant Effect on Beef}

TBA can be used to evaluate the degree of fat oxidation in beef during storage. The MDA values of beef increased throughout the storage period, and the MDA values of the samples treated with nanoparticles were significantly reduced compared with the control samples. The MDA values of the control samples increased from $0.14 \mathrm{mg} / \mathrm{kg}$ to $0.57 \mathrm{mg} / \mathrm{kg}$ at $4{ }^{\circ} \mathrm{C}$. The MDA values of beef treated with TNP were the lowest. These results were consistent with the strong DPPH scavenging ability of TNP. Compared with the control 
samples, the MDA values of the samples treated with RNNP and TNP decreased by $14.04 \%$ and $33.33 \%$ at $4{ }^{\circ} \mathrm{C}$, respectively (Figure $6 \mathrm{~b}$ ). The MDA values of the samples treated with RNNP and TNP decreased by $25.29 \%$ and $41.38 \%$ at $25{ }^{\circ} \mathrm{C}$, respectively (Figure $6 \mathrm{c}$ ).

TVB-N is a key factor for evaluating beef freshness by the degree of protein oxidation [59]. GB 2707-2016 stipulates that the TVB-N values of fresh meat are less than $15 \mathrm{mg} / 100 \mathrm{~g}$. The TVB-N values of beef in different treatment groups were shown in Figure $6 \mathrm{~d}$,e. With the increase of storage time, the TVB-N values of all samples showed an upward trend. However, the values of the samples treated with nanoparticles were significantly lower than that of the control samples, and the antioxidant effect of TNP was better than that of RNNP. When the beef was stored at $4{ }^{\circ} \mathrm{C}$ for 5 days, the TVB-N value of the control samples reached $17.47 \mathrm{mg} / 100 \mathrm{~g}$ on the fourth day, indicating that the beef was not fresh. The beef treated with TNP remained fresh on the fifth day (Figure $6 \mathrm{~d}$ ). When the beef was stored at $25^{\circ} \mathrm{C}$, the TVB-N values of control samples exceeded $15 \mathrm{mg} / 100 \mathrm{~g}$ at the 12 th hour, the beef treated with RNNP reached this value at the 16th hour, and the beef treated with TNP was still fresh at the 20th hour (Figure 6e).

These results indicated that LBP enhanced the antioxidant effect of RNNP, and TNP played an important role in delaying lipid oxidation and protein oxidation.

\subsection{The Application of Nanoparticles against S. aureus and E. coli O157:H7 on Beef}

The long-term antibacterial activity of nanoparticles against $S$. aureus and E. coli O157:H7 on beef was presented in Figure $7 \mathrm{a}-\mathrm{d}$. The initial number of $S$. aureus was $4.024 \log \mathrm{CFU} / \mathrm{g}$. The beef was stored at $4{ }^{\circ} \mathrm{C}$ for five days. The amount of $S$. aureus in the control samples increased to $6.496 \mathrm{log} \mathrm{CFU} / \mathrm{g}$, the samples treated with RNNP increased to $4.802 \log \mathrm{CFU} / \mathrm{g}$, which was a $26.08 \%$ decrease compared to the control samples, and the samples treated with TNP increased to $4.505 \log$ CFU/g, a 30.65\% decrease (Figure 7a). When it was cultured at $25{ }^{\circ} \mathrm{C}$ for five days, compared with the control samples, the number of $S$. aureus in the samples treated with RNNP decreased $1.85 \log \mathrm{CFU} / \mathrm{g}$, and the samples treated with TNP decreased $2.374 \log$ CFU/g (Figure 7b). When the nanoparticles were applied to beef with E. coli O157:H7, the number of E. coli O157:H7 was significantly increased in the control samples, with the initial population of $4.142 \mathrm{log} \mathrm{CFU} / \mathrm{g}$ reached $6.325 \log \mathrm{CFU} / \mathrm{g}$ at $4{ }^{\circ} \mathrm{C}$ and $8.803 \mathrm{log} \mathrm{CFU} / \mathrm{g}$ at $25^{\circ} \mathrm{C}$. When the beef was stored at $4{ }^{\circ} \mathrm{C}$ for five days, the beef treated with TNP showed the lowest microbial population (5.013 log CFU/g), which was obviously lower than the samples treated with RNNP (5.225 log CFU/g) (Figure 7c). When it was cultured at $25^{\circ} \mathrm{C}$ for five days, compared with the control samples, the number of E. coli O157:H7 in the samples treated with RNNP decreased by $14.78 \%$, and the samples treated with TNP decreased by $18.51 \%$ (Figure 7d). These results indicated that the polysaccharide modification improved the antibacterial effect of RNNP, and the results were consistent with the inhibition zone and the time-kill curve.

The effect of nanoparticles on the color of beef was studied in Figure $7 \mathrm{e}-\mathrm{g}$. The $\mathrm{L}^{*}$ value of beef in the samples treated with RNNP increased, the $a^{*}$ value decreased, and the $b^{*}$ value had no difference on day 0 . When the beef was treated with TNP, TNP reduced the $a^{*}$ value of beef and had no effect on the $L^{*}$ value and $b^{*}$ value. When the beef was stored at $4{ }^{\circ} \mathrm{C}$ for five days, compared with the control group, the $\mathrm{L}^{*}$ value of the group treated with nanoparticles increased, but there were no significant differences between the $\mathrm{a}^{*}$ value and $b^{*}$ value. When it was stored at $25^{\circ} \mathrm{C}$ for five days, there were no significant difference in the $L^{*}$ value, $a^{*}$ value, or the $b^{*}$ value of the group treated with nanoparticles compared with the control group. Therefore, the nanoparticles will not affect the color of beef.

The effect of nanoparticles on the PH of beef was shown in Figure 7h. It can be seen that the beef treated with nanoparticles did not change its $\mathrm{pH}$ value on the day zero. When the beef was stored at $4{ }^{\circ} \mathrm{C}$ for five days, the $\mathrm{pH}$ value of the control group and the group treated with nanoparticles did not change much compared with day zero. The result may be the result of the increase in $\mathrm{pH}$ after the beef has been acidified. When it was stored at $25{ }^{\circ} \mathrm{C}$ for 5 days, the $\mathrm{pH}$ value increased to $8.82 \pm 0.02,8.72 \pm 0.01,8.61 \pm 0.02$, respectively, 
and the increase rate of $\mathrm{pH}$ in the samples treated with nanoparticles was lower than that of the control group. These results showed that nanoparticles can inhibit the growth of microorganisms, and the antibacterial effect of TNP was better than that of RNNP.
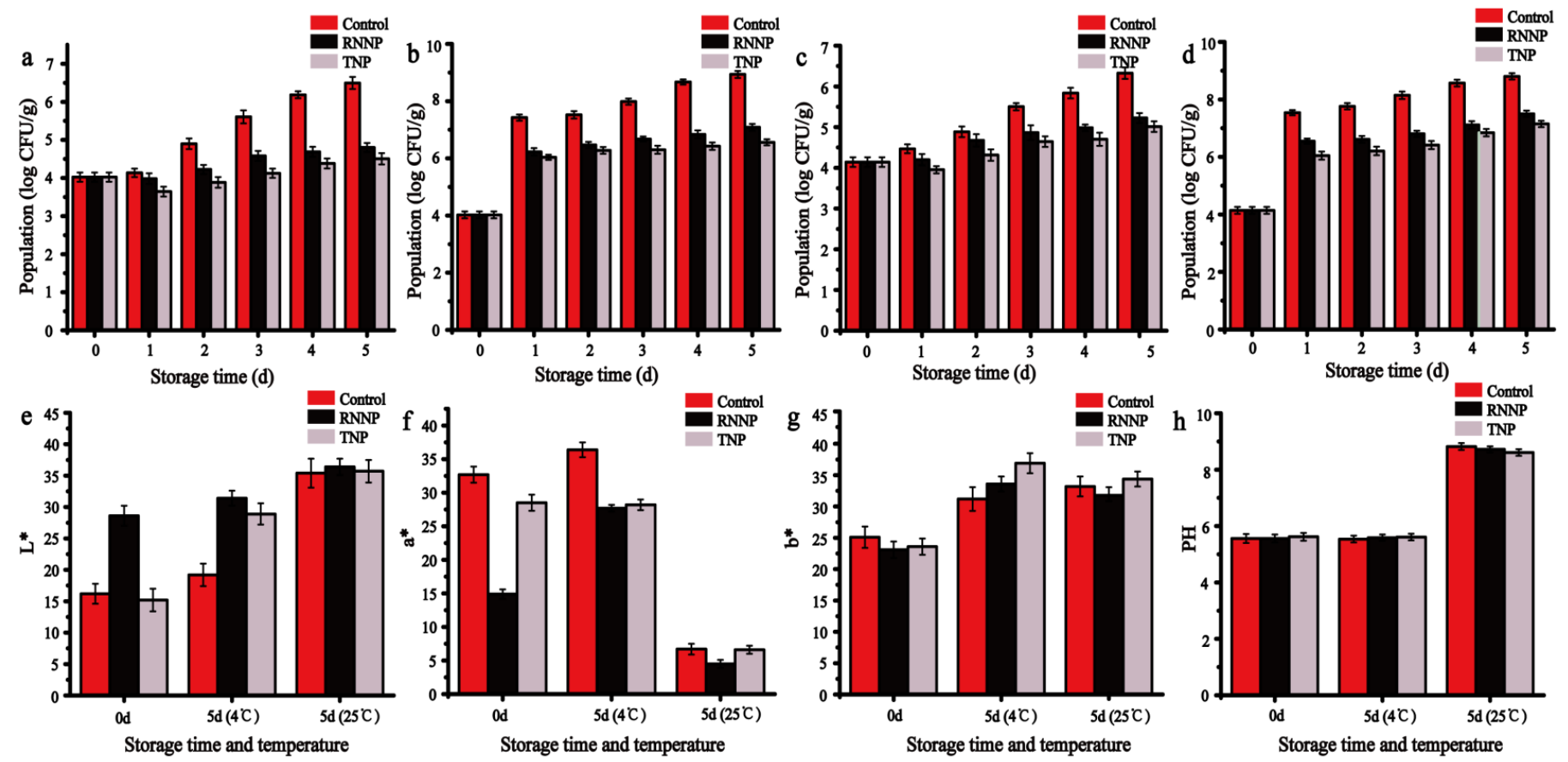

Figure 7. The application of nanoparticles in beef including antibacterial activity of RNNP and TNP against $S$. aureus at $4{ }^{\circ} \mathrm{C}(\mathbf{a})$ and $25^{\circ} \mathrm{C}(\mathbf{b})$; The antibacterial activity of RNNP and TNP against $E$. coli O157:H7 at $4{ }^{\circ} \mathrm{C}$ (c) and $25{ }^{\circ} \mathrm{C}(\mathbf{d})$; color analysis of beef treated with RNNP and TNP at $4{ }^{\circ} \mathrm{C}$ and $25^{\circ} \mathrm{C}(\mathbf{e}-\mathbf{g}) ; \mathrm{PH}$ of beef treated with RNNP and TNP at $4{ }^{\circ} \mathrm{C}$ and $25^{\circ} \mathrm{C}(\mathbf{h})$.

The effect of nanoparticles on the texture of beef after five days of storage at 4 and $25{ }^{\circ} \mathrm{C}$ was presented in Table 2 . The adhesiveness, resilience and cohesion of beef treated with RNNP increased significantly, and the resilience and cohesion of beef treated with TNP decreased significantly on day zero. When the beef was stored at 4 or $25{ }^{\circ} \mathrm{C}$ for 5 days, the springiness and gumminess of beef had no significant change. Other values of the group treated with nanoparticles were better than the control group. These results showed that nanoparticles could delay the change in the texture of the beef.

Table 2. Effect of nanoparticles on the quality of beef after five days of storage at $4{ }^{\circ} \mathrm{C}$ and $25{ }^{\circ} \mathrm{C}$.

\begin{tabular}{|c|c|c|c|c|c|c|c|c|}
\hline \multirow{2}{*}{ Treatment } & \multicolumn{8}{|c|}{ Texture Parameters } \\
\hline & & Hardness (g) & $\begin{array}{c}\text { Adhesiveness } \\
\text { (g.sec) }\end{array}$ & Resilience (\%) & Cohesion & Springiness (\%) & Gumminess & Chewiness \\
\hline \multirow{3}{*}{$0 \mathrm{~d}$} & Control & $25.916 \pm 0.482 \mathrm{a}$ & $-47.244 \pm 1.572^{\mathrm{C}}$ & $47.372 \pm 2.758 \mathrm{~b}$ & $0.801 \pm 0.003 \mathrm{~b}$ & $51.237 \pm 2.573^{a}$ & $8.235 \pm 0.628 \mathrm{a}$ & $3.514 \pm 0.089 \mathrm{~b}$ \\
\hline & RNNP & $25.985 \pm 0.893 \mathrm{a}$ & $-19.499 \pm 0.724^{a}$ & $51.061 \pm 5.641 \mathrm{a}$ & $0.853 \pm 0.004 \mathrm{a}$ & $53.423 \pm 3.091 \mathrm{a}$ & $8.703 \pm 0.773 \mathrm{a}$ & $3.825 \pm 0.068$ a \\
\hline & TNP & $26.328 \pm 0.737^{\mathrm{a}}$ & $-26.424 \pm 0.857 \mathrm{~b}$ & $40.243 \pm 2.986^{C}$ & $0.763 \pm 0.002 \mathrm{c}$ & $47.279 \pm 2.942 \mathrm{a}$ & $8.255 \pm 0.395 \mathrm{a}$ & $3.301 \pm 0.046^{\mathrm{C}}$ \\
\hline \multirow{3}{*}{$5 \mathrm{~d}\left(4^{\circ} \mathrm{C}\right)$} & Control & $18.855 \pm 0.961 \mathrm{~b}$ & $-41.829 \pm 1.147^{c}$ & $38.297 \pm 2.675^{\mathrm{a}}$ & $0.597 \pm 0.002^{c}$ & $39.582 \pm 1.862^{\mathrm{a}}$ & $6.425 \pm 0.413^{a}$ & $2.125 \pm 0.031^{\mathrm{C}}$ \\
\hline & RNNP & $20.275 \pm 0.725 \mathrm{~b}$ & $-13.351 \pm 1.426^{a}$ & $45.847 \pm 4.842^{\mathrm{a}}$ & $0.752 \pm 0.006^{a}$ & $43.51 \pm 3.427^{\mathrm{a}}$ & $7.214 \pm 0.386^{a}$ & $2.532 \pm 0.073 \mathrm{a}$ \\
\hline & TNP & $23.016 \pm 0.515^{a}$ & $-25.934 \pm 0.984 b$ & $38.961 \pm 2.967^{a}$ & $0.665 \pm 0.005 \mathrm{~b}$ & $40.21 \pm 2.074 \mathrm{a}$ & $7.013 \pm 0.514^{\mathrm{a}}$ & $2.289 \pm 0.062 \mathrm{~b}$ \\
\hline \multirow{3}{*}{$5 \mathrm{~d}\left(25^{\circ} \mathrm{C}\right)$} & Control & $11.616 \pm 0.472^{c}$ & $-34.455 \pm 0.963^{c}$ & $30.566 \pm 1.653^{\mathrm{b}}$ & $0.468 \pm 0.002 \mathrm{c}$ & $32.221 \pm 1.143 \mathrm{a}$ & $5.438 \pm 0.327 \mathrm{a}$ & $1.752 \pm 0.057 \mathrm{c}$ \\
\hline & RNNP & $14.734 \pm 0.357 \mathrm{~b}$ & $-10.345 \pm 1.273^{a}$ & $40.968 \pm 3.547^{\mathrm{a}}$ & $0.638 \pm 0.004 \mathrm{a}$ & $37.061 \pm 1.984^{\mathrm{a}}$ & $6.217 \pm 0.551^{a}$ & $2.316 \pm 0.071^{\mathrm{a}}$ \\
\hline & TNP & $19.564 \pm 0.416^{\mathrm{a}}$ & $-21.362 \pm 1.527 b$ & $36.805 \pm 1.604^{\mathrm{a}}$ & $0.615 \pm 0.008 \mathrm{~b}$ & $35.415 \pm 2.573^{a}$ & $5.941 \pm 0.426^{a}$ & $2.046 \pm 0.054 \mathrm{~b}$ \\
\hline
\end{tabular}

Values are expressed as mean \pm SD. ${ }^{\text {a-c }}$ Different superscript within the same column represent significant differences $(p<0.05)$.

\section{Conclusions}

In this paper, we aim to prepare TNP with high encapsulation efficiency and high stability to make up for the instability of protein nanoparticles. This is a new type of TNP containing dual active ingredients, with better antibacterial and antioxidant activities. TNP were prepared by hydrophobic interaction and electrostatic interaction using REO 
as antibacterial materials, nisin as antibacterial materials and peptide-based materials of nanoparticles, and LBP as modified materials. TNP had good particle size $(211.5 \mathrm{~nm})$, better dispersion (PDI $=0.241$ ), and a uniform earth shape. The encapsulation efficiency of TNP reached $32 \%$. UV and fluorescence spectra showed that the increase in the encapsulation efficiency of TNP might be caused by the interaction between LBP and nisin, which exposed more water dispersing bonds. After the addition of LBP, the physical stability, thermal stability and storage stability of TNP were significantly improved. The application of TNP on beef presented a favorable preservation effect without affecting its color and texture. Therefore, TNP are suitable carriers of active substances and have a wide range of application prospects.

Author Contributions: Conceptualization, L.L. and H.C.; methodology, L.L., C.L. (Chencheng Luo), C.L. (Changzhu Li), X.C. and H.C.; software, X.C.; validation, C.L. (Chencheng Luo); formal analysis, L.L.; investigation, X.C. and L.L.; resources, C.L. (Changzhu Li); data curation, C.L. (Chencheng Luo); writing — original draft preparation, C.L. (Chencheng Luo) and C.L. (Changzhu Li); writingreview and editing, L.L. and H.C.; visualization, L.L. and X.C.; supervision, L.L. and H.C.; project administration, H.C.; funding acquisition, L.L. and H.C. All authors have read and agreed to the published version of the manuscript.

Funding: This research was supported by the State Key Laboratory of Utilization of Woody Oil Resource (Grant No. 2019XK2002), National Natural Science Foundation of China (Grant No. 31972172), Natural Science Foundation of Jiangsu Province (Grant No. BK20201417), Jiangsu Province Research Fund (Grant No. JNHB-131) and Jiangsu University Research Fund (Grant No. 11JDG050).

Institutional Review Board Statement: Not applicable.

Informed Consent Statement: Not applicable.

Data Availability Statement: Not applicable.

Conflicts of Interest: The authors declare that they have no conflicts of interest.

\section{References}

1. Bintsis, T. Foodborne pathogens. AIMS Microbiol. 2017, 3, 529. [CrossRef] [PubMed]

2. Umesha, S.; Manukumar, H.M. Advanced molecular diagnostic techniques for detection of food-borne pathogens: Current applications and future challenges. Crit. Rev. Food Sci. Nutr. 2018, 58, 84-104. [CrossRef] [PubMed]

3. WHO. Food Safety 2014. Available online: https://www.who.int/news-room/fact-sheets/detail/food-safety (accessed on 23 July 2021).

4. Gugsa, G.; Ahmed, M. Review on Major Food-Borne Zoonotic Bacterial Pathogens. J. Trop. Med. 2020, 4674235. [CrossRef]

5. Bahrami, A.; Delshadi, R.; Assadpour, E.; Jafari, S.M.; Williams, L. Antimicrobial-loaded nanocarriers for food packaging applications. Adv. Colloid Interface Sci. 2020, 278, 102140. [CrossRef]

6. Rehman, A.; Jafari, S.M.; Aadil, R.M.; Assadpour, E.; Randhawa, M.A.; Mahmood, S. Development of active food packaging via incorporation of biopolymeric nanocarriers containing essential oils. Trends Food Sci. Technol. 2020, 101, 106-121. [CrossRef]

7. Nikolic, M.V.; Vasiljevic, Z.Z.; Auger, S.; Vidic, J. Metal oxide nanoparticles for safe active and intelligent food packaging. Trends Food Sci. Technol. 2021, 116, 655-668. [CrossRef]

8. Chaudhary, S.; Kumar, V.; Sharma, V.; Sharma, R.; Kumar, S. Chitosan nanoemulsion: Gleam into the futuristic approach for preserving the quality of muscle foods. Int. J. Biol. Macromol. 2022, 199, 121-137. [CrossRef]

9. Fucinos, C.; Fucinos, P.; Amado, I.R.; Miguez, M.; Fajardo, P.; Pastrana, L.M.; Rua, M.L. Chapter 28-Smart Nanohydrogels for Controlled Release of Food Preservatives. Antimicrob. Food Packag. 2016, 28, 349-362. [CrossRef]

10. Zhou, C.; Abdel-Samie, M.A.; Li, C.; Cui, H.; Lin, L. Active packaging based on swim bladder gelatin/galangal root oil nanofibers: Preparation, properties and antibacterial application. Food Packag. Shelf Life 2020, 26, 100586. [CrossRef]

11. Lin, L.; Wu, J.; Li, C.; Chen, C.; Cui, H. Fabrication of a dual-response intelligent antibacterial nanofiber and its application in beef preservation. LWT 2022, 154, 112606. [CrossRef]

12. Zhu, Y.; Li, C.; Cui, H.; Lin, L. Plasma enhanced-nutmeg essential oil solid liposome treatment on the gelling and storage properties of pork meat batters. J. Food Eng. 2020, 266, 109696. [CrossRef]

13. Cui, H.; Zhang, C.; Li, C.; Lin, L. Inhibition of Escherichia coli O157:H7 biofilm on vegetable surface by solid T liposomes of clove oil. LWT-Food Sci. Technol. 2020, 117, 108656. [CrossRef]

14. Zhang, Q.; Zhou, Y.; Yue, W.; Qin, W.; Dong, H.; Vasanthan, T. Nanostructures of protein-polysaccharide complexes or conjugates for encapsulation bioactive compounds. Trends Food Sci. Technol. 2021, 109, 169-196. [CrossRef] 
15. Zhou, P.; Feng, R.; Luo, Z.; Wang, L.; Gao, L. Synthesis, identification and bioavailability of Juglans regia L. polyphenolsHohenbuehelia serotina polysaccharides nanoparticles. Food Chem. 2020, 329, 127158. [CrossRef]

16. Li, G.; Chen, Q.; Su, C.; Wang, H.; He, S.; Liu, J.; Nag, A.; Yuan, Y. Soy protein-polysaccharide complex coacervate under physical treatment: Effects of $\mathrm{pH}$, ionic sttrength and polysaccharide type. Innov. Food Sci. Emerg. Technol. 2021, 68, 102612. [CrossRef]

17. Li, H.; Yuan, Y.; Zhu, J.; Wang, T.; Wang, D.; Xu, Y. Zein/soluble soybean polysaccharide composite nanoparticles for encapsulation and oral delivery of lutein. Food Hydrocoll. 2020, 103, 105715. [CrossRef]

18. Wang, Y.; Guo, W.; Gao, X.; Li, G.; He, S. Sodium caseinate and soluble soybean polysaccharide complex as nanocarriers of curcumin. J. Food Meas. Charact. 2021, 15, 478-483. [CrossRef]

19. Alex, L.C.; Carolina, M.J.; Danyxa, P.H.; Silvia, G. Cassava starch films containing rosemary nanoparticles produced by solvent displacement method. Food Hydrocoll. 2017, 71, 26-34. [CrossRef]

20. Adriana, M.O.; Gatalina, M.B.; Miguel, A.E.; Miguel, A.J.; Silvia, M. New insights into antibacterial and antioxidant activities of rosemary essential oils and their main components. Food Control. 2013, 31, 189-195. [CrossRef]

21. Catalina, S.R.; Karina, A.; Victoria, R.; Adrian, A.V.; Silvia, M. Synergistic antioxidant and antibacterial activity of rosemary plus butylated derivatives. Food Chem. 2009, 115, 456-461. [CrossRef]

22. Cui, H.; Wu, J.; Li, C.; Lin, L. Improving anti-listeria activity of cheese packaging via nanofiber containing nisin-loaded nanoparticles. LWT-Food Sci. Technol. 2017, 81, 233-242. [CrossRef]

23. Bai, F.; Guo, D.; Wang, Y.; Zhang, S.; Li, J.; Zhi, K.; Shi, C.; Xia, X. The combined bactericidal effect of nisin and thymoquinone against Listeria monocytogenes in Tryptone Soy Broth and sterilized milk. Food Control. 2022, 135, 108771. [CrossRef]

24. Mariel, C.; Héctor, B.E.; Omar, N.M.; Jose, P.; Ruth, P.; Edith, P. Optimization of the antioxidant and antimicrobial response of the combined effect of nisin and avocado byproducts. LWT-Food Sci. Technol. 2016, 65, 46-52. [CrossRef]

25. Luo, L.; Wu, Y.; Liu, C.; Zou, Y.; Huang, L.; Liang, Y.; Ren, J.; Liu, Y.; Lin, Q. Elaboration and characterization of curcumin-loaded soy soluble polysaccharide (SSPS)-based nanocarriers mediated by antimicrobial. Food Chem. 2021, 336, 127669. [CrossRef]

26. Qian, J.; Chen, Y.; Wang, Q.; Zhao, X.; Yang, H.; Gong, F.; Guo, H. Preparation and antimicrobial activity of pectin-chitosan embedding nisin microcapsules. Eur. Polym. J. 2021, 157, 110676. [CrossRef]

27. Prombutara, P.; Kulwatthanasal, Y.; Supaka, N.; Sramala, I.; Chareonpornwattana, S. Production of nisin-loaded solid lipid nanoparticles for sustained antimicrobial activity. Food Control. 2012, 24, 184-190. [CrossRef]

28. Gharsallaoui, A.; Oulahal, N.; Joly, C.; Degraeve, P. Nisin as a food preservative: Part 1: Physicochemical properties, antimicrobial activity, and main uses. Crit. Rev. Food Sci. Nutr. 2016, 56, 1262-1274. [CrossRef]

29. Cleveland, j.; Montville, T.J.; Nes, I.F.; Chikindas, M.L. Bacteriocins: Safe, natural antimicrobials for food preservation. Int. J. Food Microbiol. 2001, 71, 1-20. [CrossRef]

30. Cui, H.; Dai, Y.; Lin, L. Enhancing antibacterial efficacy of nisin in pork by poly-c-glutamic acid/poly-L-lysine nanoparticles encapsulation. J. Food Saf. 2018, 38, e12475. [CrossRef]

31. Imran, K.; Deog-Hwan, O. Integration of nisin into nanoparticles for application in foods. Innov. Food Sci. Emerg. Technol. 2016, 34, 376-384. [CrossRef]

32. Malheiros, P.; Daroit, D.J.; Brandelli, A. Food applications of liposome-encapsulated antimicrobial peptides. Trends Food Sci. Technol. 2010, 21, 284-292. [CrossRef]

33. Aisaggaf, M.S.; Moussa, S.H.; Elguindy, N.M.; Tayel, A.A. Fungal chitosan and Lycium barbarum extract as anti-Listeria and quality preservatives in minced catfish. Int. J. Biol. Macromol. 2017, 104, 854-861. [CrossRef] [PubMed]

34. Wang, Y.; Bai, F.; Luo, Q.; Wu, M.; Song, G.; Zhang, H.; Cao, J.; Wang, Y. Lycium barbarum polysaccharides grafted with doxorubicin: An efficient $\mathrm{pH}$-responsive anticancer drug delivery system. Int. J. Biol. Macromol. 2019, 121, 964-970. [CrossRef]

35. Duan, G.L.; Yu, X. Isolation, purification, characterization, and antioxidant activity of low-molecular-weight polysaccharides from Sparassis latifolia. Int. J. Biol. Macromol. 2019, 137, 1112-1120. [CrossRef] [PubMed]

36. Liu, K.; Zha, X.; Li, Q.; Pan, L.; Luo, J. Hydrophobic interaction and hydrogen bonding driving the self-assembling of quinoa protein and flavonoids. Food Hydrocoll. 2021, 118, 106807. [CrossRef]

37. Hamdeni, I.; Slim, S.; Sanaa, A.; Louhaichi, M.; Boulila, A.; Bettaieb, T. Rosemary essential oil enhances culture establishment and inhibits contamination and enzymatic browning: Applications for in vitro propagation of Aloe vera L. S. Afr. J. Bot. 2021 [CrossRef]

38. Lin, L.; Chen, W.; Li, C.; Cui, H. Enhancing stability of Eucalyptus citriodora essential oil by solid nanoliposomes encapsulation Ind. Crops Prod. 2019, 140, 111615. [CrossRef]

39. Surendhiran, D.; Li, C.; Cui, H.; Lin, L. Fabrication of high stability active nanofibers encapsulated with T pomegranate peel extract using chitosan/PEO for meat preservation. Food Packag. Shelf Life 2020, 23, 100439. [CrossRef]

40. Cui, H.; Wu, J.; Li, C.; Lin, L. Anti-listeria effects of chitosan-coated nisin-silica liposome on Cheddar cheese. J. Dairy Sci. 2016, 99, 8598-8606. [CrossRef]

41. Thakar, M.A.; Jha, S.S.; Phasinam, K.; Manne, R.; Qureshi, Y.; Babu, V. X ray diffraction (XRD) analysis and evaluation of antioxidant activity of copper oxide nanoparticles synthesized from leaf extract of Cissus vitiginea. Mater. Today Proc. 2021. [CrossRef]

42. Lin, L.; Gu, Y.; Cui, H. Novel electrospun gelatin-glycerin- $\varepsilon$-Poly-lysine nanofibers for controlling Listeria monocytogenes on beef. Food Packag. Shelf Life 2018, 18, 21-30. [CrossRef] 
43. Cui, H.; Yang, X.; Mohamed, A.; Lin, L. Cold plasma treated phlorotannin/Momordica charantia polysaccharide nanofiber for active food packaging. Carbohydr. Polym. 2020, 239, 116214. [CrossRef]

44. Zhang, J.; Wang, Y.; Pan, D.D.; Cao, J.X.; Shao, X.F.; Chen, Y.J. Effect of black pepper essential oil on the quality of fresh pork during storage. Meat Sci. 2016, 117, 130-136. [CrossRef]

45. Lin, L.; Gu, Y.; Cui, H. Moringa oil/chitosan nanoparticles embedded gelatin nanofibers for food T packaging against Listeria monocytogenes and Staphylococcus aureus on cheese. Food Packag. Shelf Life 2019, 19, 86-93. [CrossRef]

46. Chopra, M.; Kaur, P.; Bernela, M.; Thakur, R. Surfactant assisted nisin loaded chitosan-carageenan nanocapsule synthesis for controlling food pathogens. Food Control. 2014, 37, 158-164. [CrossRef]

47. Chang, R.; Lu, H.; Li, M.; Zhang, S.; Xiong, L.; Sun, Q. Preparation of extra-small nisin nanoparticles for enhanced antibacterial activity after autolave treatment. Food Chem. 2018, 245, 756-760. [CrossRef]

48. Narahari, A.; Swamy, M.J. Tryptophan exposure and accessibility in the chitooligosaccharide-specific phloem exudate lectin from pumpkin (Cucurbita maxima). A fluorescence study. J. Photochem. Photobiol. B Biol. 2009, 97, 40-47. [CrossRef]

49. Madaeni, S.S.; Rostami, E. Spectroscopic investigation of the interaction of BSA with cationic surfactant. Chem. Eng. Technol. 2010, 31, 1265-1271. [CrossRef]

50. Li, J.; Pan, D.; Yi, J.; Hao, L.; Kang, Q.; Liu, X.; Lu, L.; Lu, J. Protective effect of $\beta$-cyclodextrin on stability of nisin and corresponding interactions involved. Carbohydr. Polym. 2019, 223, 115115. [CrossRef]

51. Radhakrishna, M.; Grimaldi, J.; Belfort, G.; Kumar, S.K. Stability of Proteins Inside a Hydrophobic Cavity. Am. Chem. Soc. 2003, 29, 8922-8928. [CrossRef]

52. Dhouibi, I.; Masmoudi, F.; Bouaziz, M.; Masmoudi, M. A study of the anti-corrosive effects of essential oils of rosemary and myrtle for copper corrosion in chloride media. Arab. J. Chem. 2021, 14, 102961. [CrossRef]

53. Stamarkou, M.; Oikonomopoulou, V.; Missirli, T.; Thanassoulia, I.; Krokida, M. Encapsulation of Rosemary Essential Oil into Biodegradable Polymers for Application in Crop Management. J. Polym. Environ. 2020, 28, 2161-2177. [CrossRef]

54. Krivorotova, T.; Cirkovas, A.; Maciulyte, S.; Staneviciene, R.; Budriene, S.; Serviene, E.; Sereikaite, J. Nisin-loaded pectin nanoparticles for food preservation. Food Hydrocoll. 2016, 54, 49-56. [CrossRef]

55. Tan, H.F.; Gan, C.Y. Polysaccharide with antioxidant, amylase inhibitory and ACE inhibitory activities from Momordica charantia. Int. J. Biol. Macromol. 2016, 85, 487-496. [CrossRef]

56. Gong, F.; Qian, J.; Chen, Y.; Yao, S.; Tong, J.; Guo, H. Preparation and properties of gum arabic cross-link binding nisin microparticles. Carbohydr. Polym. 2018, 197, 608-613. [CrossRef]

57. Cui, H.; Lu, J.; Li, C.; Rashed, M.; Lin, L. Antibacterial and physical effects of cationic starch nanofibers containing carvacrol@casein nanoparticles against Bacillus cereus in soy products. Inter. J. Food Microbiol. 2022, 364, 109530. [CrossRef]

58. Zhang, C.; Zhao, M.; Zou, H.; Zhang, X.; Sheng, R.; Zhang, Y.; Zhang, B.; Li, C.; Qi, Y. An enhanced antibacterial nanoflowers AgPW@PDA@Nisin constructer from polyoxometalate and nisin. J. Inorg. Biochem. 2020, 212, 111212. [CrossRef]

59. Li, Y.; Tang, X.; Shen, Z.; Dong, S. Prediction of total volatile basic nitrogen (TVB-N) content of chilled beef for freshness evaluation by using viscoelasticity based on airflow and laser technique. Food Chem. 2019, 287, 126-132. [CrossRef] 